Original Paper http://ajol.info/index.php/ijbcs http://indexmedicus.afro.who.int

\title{
Changes in activities of tissues enzymes in rats administered Ficus exasperata leaf extract
}

\author{
Olu Israel OYEWOLE * and Johnson Olaleye OLADELE \\ Phytomedicine and Toxicology Laboratories, Biochemistry Unit, Department of Chemical Sciences, \\ Faculty of Basic and Applied Sciences, Osun State University, Osogbo, Nigeria. \\ *Corresponding author; E-mail: ioluoye@yahoo.com; Tel: +2348066808560
}

\begin{abstract}
This study evaluates the effects of methanolic extract of Ficus exasperata leaf on the activities of some enzymes in the serum, liver, kidney and heart of albino rats. Twenty four rats were sorted into four groups: Group A (control) received distilled water while rats in groups B, C and D were administered graded doses $(100,200$ and $500 \mathrm{mg} / \mathrm{kg} \mathrm{bw})$ of methanolic leaf extract of Ficus exasperata respectively for 14 days. Activities of alanine aminotransferase (ALT), aspartate aminotransferase (AST), alkaline phosphatase (ALP) and acid phosphatase (ACP) were determined in the serum and tissues. Results obtained showed that administration of graded doses of Ficus exasperata leaf extract to rats caused significant increase $(p<0.05)$ in growth rate compared to the control. Rats administered $500 \mathrm{mg} / \mathrm{kg}$ bw of the extract recorded significant decrease in tissues levels of the enzymes accompanied with their elevation in the serum indicating toxicity at this dose. There was also a significant increase in relative organ weight in rats who received $500 \mathrm{mg} / \mathrm{kg}$ bw of the extract. Rats administered low and moderate doses (100 and $200 \mathrm{mg} / \mathrm{kg} \mathrm{bw})$ of the extract showed no significant alteration in enzyme activities in the serum and tissues as well as relative organ weight. The results suggest that intake of leaf extract of Ficus exasperata as a medicinal remedy is safe at lower dose and could help to promote growth. The extract might however be toxic to the organs when taken at high doses.
\end{abstract}

(C) 2017 International Formulae Group. All rights reserved.

Keywords: Transaminases, phosphatases, Ficus exasperata, liver, kidney, heart

\section{INTRODUCTION}

The use of medicinal plants and herbal remedies in combating many diseases are becoming indispensable and has constituted an integral part of Primary Health Care systems in many nations of the world. Ficus exasperata is a terrestrial Afro-tropical shrub with ovate leaves that grows up to about $20 \mathrm{~m}$ tall and prefers evergreen and secondary forest habitats (Lansky and Paavilainen,
2011). It is popularly known as sandpaper leaf tree in Nigeria due to the rough surface of the leaves which is used industrially to smoothen furniture surfaces.

A number of pharmacological activities have been attributed to different parts (fruit, leaf, sap, bark, and root) of Ficus exasperata. The plant is used traditionally as analgesic, anti-arthritic, anti-diarrhea, antidysentery, anti-diuretic, abortifacient and also 
in general debility (Bafor et al., 2009; Ikpeme et al., 2010; Ahmed et al., 2012). The leaf of Ficus exasperata is chiefly employed in the treatment of many ailments including kidney disorders, venereal diseases, hemostatic ophthalmia, coughs, hemorrhoids, epilepsy, high blood pressure, rheumatism, arthritis, cancer, intestinal pains, bleeding and wounds (Mshana et al., 2001; Cousins and Michael, 2002; Amonkan et al., 2010). Decoction of the leaves is used for stomach disorders (Woode et al., 2011).

Reports from previous studies have established the antimicrobial effects (Odunbaku et al., 2008), antiulcerogenic effect (Joseph and Raj, 2010), arterial blood pressure reducing effect (Ayinde et al., 2007), anti-inflammatory, antipyretic and antinociceptive effects (Woode et al., 2009), ease childbirth and hastening expulsion of placenta in cows (Ijeh and Ukweni, 2007), anti-ulcer, anti-diabetic and lipid lowering properties (Sonibare et al., 2006; Oyewole et al., 2013). Base on this background, this study was designed to assess the toxic effects of methanolic leaf extract of Ficus exasperata on the liver, kidney and heart of rats by measuring the levels of some key enzymes in the serum and tissues.

\section{MATERIALS AND METHODS}

\section{Reagents/chemicals}

Enzyme diagnostic kits (ALT, AST, ALP and ACP) were obtained from Randox Laboratories Limited, United Kingdom. All other chemicals were of analytical grade and were obtained from BDH Limited, Poole England.

\section{Collection of plant material and preparation of extracts}

Fresh samples of Ficus exasperata leaves were collected at Oke Baale Area, Osogbo, Nigeria. The plant was identified at the Botany Unit, Department of Biological Sciences, Osun State University, Osogbo, Nigeria. Pressed and dried samples of the plant were deposited in the University herbarium for future reference. The samples were air dried for 60 days and pulverized into powder using an electrical blender. The powdered leaf materials were cold-macerated with 6 volumes of $80 \%$ methanol for 14 days. Crude extract was obtained by filtration followed by evaporation of the solvent in a rotatory evaporator. The paste was weighed and used to prepare the stock solution for administration.

\section{Experimental animals}

Twenty four male Wistar albino rats were obtained at weaning age (3 weeks old, average weight $60 \mathrm{~g}$ ) and raised to maturity (average weight $160 \mathrm{~g}$ ) at the Central Animal House, Osun State University, Osogbo, Nigeria. The rats were kept in ventilated cage at optimum temperature and $12 \mathrm{hrs}$ light/dark cycle and fed with commercial grower smash and water ad libitum. The experiment was carried out in accordance with current guidelines established for the care of laboratory animals.

\section{Experimental design and dose regimen}

The twenty four rats were sorted into four (4) different groups containing six (6) rats each. Group A served as control and were administered distilled water while groups B, C and D were administered varying doses of Ficus exasperata leaf extract (100, 200 and 
$500 \mathrm{mg} / \mathrm{kg}$ bw respectively) for 14 days. Average body weight of each group were taken and recorded daily. Administration of extract was done using the gavage method.

\section{Preparation of serum}

The rats were weighed and sacrificed after $24 \mathrm{hrs}$ of last dose treatment by cervical dislocation. The jugular vein was cut and blood collected into plain bottles. The blood was allowed to clot and centrifuged at 4000 rpm for 30 min to obtain the serum. The serum obtained was stored in a refrigerator at $4{ }^{\circ} \mathrm{C}$ for biochemical analysis.

\section{Preparation of tissue homogenates}

The animals were quickly dissected and the tissues (liver, kidney and heart) immediately excised, rinsed with $\mathrm{KCl}$, blotted with filter paper and weighed. They were then chopped into bits and homogenized in 4 volumes $0.1 \mathrm{M}$ Tris- $\mathrm{KCl}$ ( $\mathrm{pH}$ 7.4) using a Teflon homogenizer. The resulting homogenate was centrifuged at $12,500 \mathrm{~g}$ for $15 \mathrm{~min}$ in a cold centrifuge $\left(4{ }^{\circ} \mathrm{C}\right)$ to obtain the post mitochondrial fraction. The supernatant was collected and used for biochemical analysis.

\section{Estimation of biochemical parameters}

Biochemical assays for ALT, AST, ALP and ACP were determined in the serum and tissues using commercially available enzymatic test kits (Randox Laboratory Ltd, UK) following the manufacturer's instructions. AST and ALT activities were measured based on the principle and methods of Reitman and Frankel (1957). ALP and ACP activities were assayed using the method of Armstrong (1964) and Wright and Plummer
(1974) respectively based on their ability to hydrolyse p-nitrophenylphosphate to give phosphate and p-nitrophenol.

\section{Statistical analysis}

Results obtained were presented as mean \pm SD. The mean value and standard deviation were calculated using the Microsoft Excel software (Microsoft Corporation, Redmond, WA). Variation within the control and experimental groups were analyzed and compared by one-way analysis of variance (ANOVA) using the Graph Pad Prism Software (GPPS). Values of $\mathrm{p}<0.05$ were taken as statistically significant.

\section{RESULTS}

Figure 1 shows a significant increase $(p<0.05)$ in growth rate of rats administered varying concentrations of Ficus exasperata leaf compared with the control. There was also a significant increase in relative organ weight (liver, kidney and heart) of rats administered $500 \mathrm{mg} / \mathrm{kg}$ bw of the extract but lower and moderate dose (100 and $200 \mathrm{mg} / \mathrm{kg}$ bw) did not alter relative organ weight compared to the control as observed in Table 1 .

It can be seen in Figures 2, 3, 4 and 5 that rats administered higher dose $(500 \mathrm{mg} / \mathrm{kg}$ bw) of the extract recorded significant decrease in ALT, AST, ALP and ACP in all tissues (kidney, liver and heart) accompanied with their elevation in the serum compared with the control. There was no significant alteration in enzyme activities in the serum and tissues of rats administered low and moderate doses (100 and $200 \mathrm{mg} / \mathrm{kg} \mathrm{bw})$ extract compared with the control. 


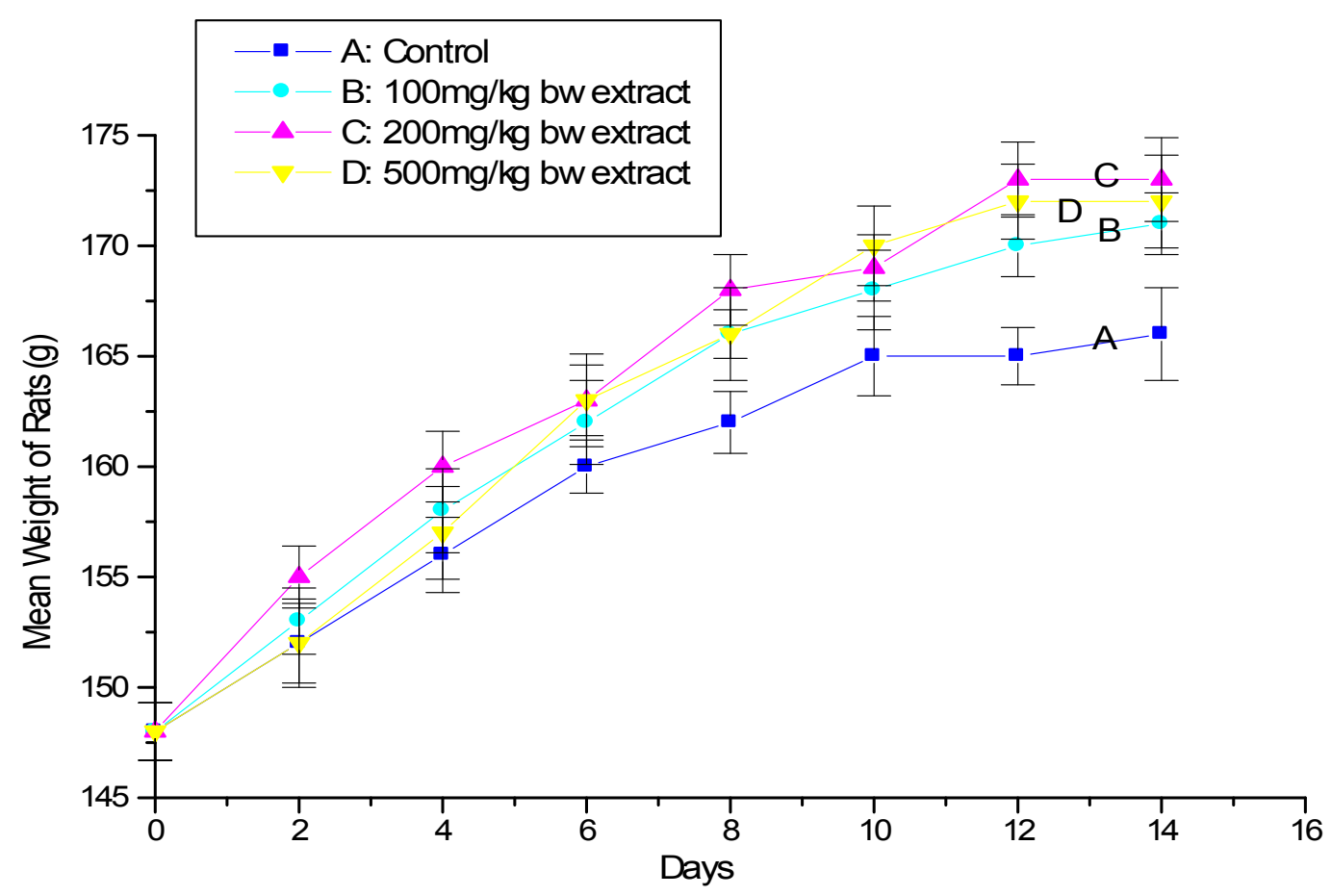

Figure 1: Growth pattern of experimental rats administered leaf extract of Ficus exasperata.

Table 1: Relative organ weight ( $\mathrm{g} / 100 \mathrm{~g}$ body weight) of rats administered leaf extract of Ficus exasperata.

\begin{tabular}{lccc}
\hline Group & Liver & Kidney & Heart \\
\hline A: Control & $3.28 \pm 0.23$ & $1.12 \pm 0.11$ & $0.38 \pm 0.04$ \\
B: $100 \mathrm{mg} / \mathrm{kg} \mathrm{bw}$ extract & $3.32 \pm 0.25$ & $1.16 \pm 0.13$ & $0.41 \pm 0.02$ \\
C: $200 \mathrm{mg} / \mathrm{kg} \mathrm{bw}$ extract & $3.31 \pm 0.20$ & $1.17 \pm 0.12$ & $0.39 \pm 0.04$ \\
D: $500 \mathrm{mg} / \mathrm{kg}$ bw extract & $3.89 \pm 0.21^{*}$ & $1.42 \pm 0.16^{*}$ & $0.59 \pm 0.03^{*}$
\end{tabular}

Values are expressed as mean of 6 determinations \pm SD; Values in asterisk are significantly different from the control at $\mathrm{p}<0.05$. 


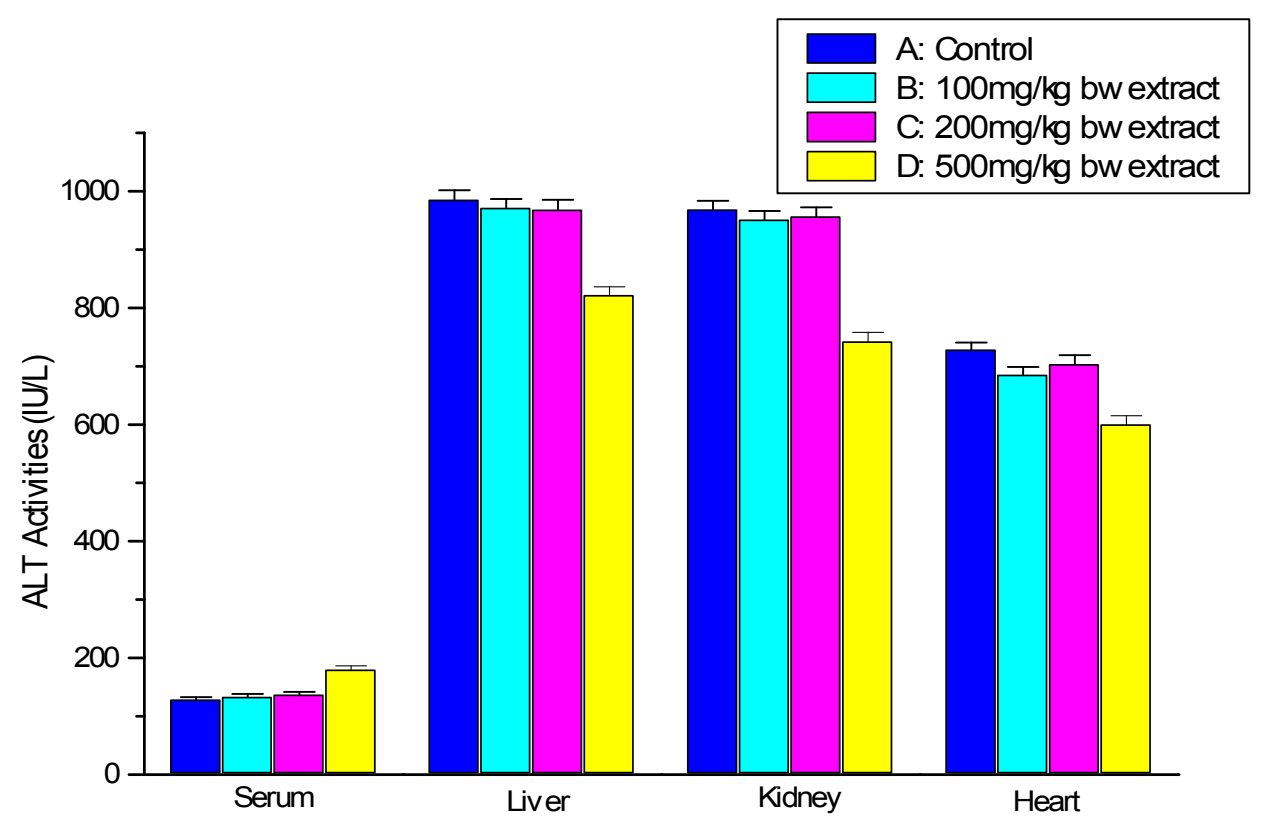

Figure 2: ALT activities in serum and tissues of rats administered leaf extract of Ficus exasperata.

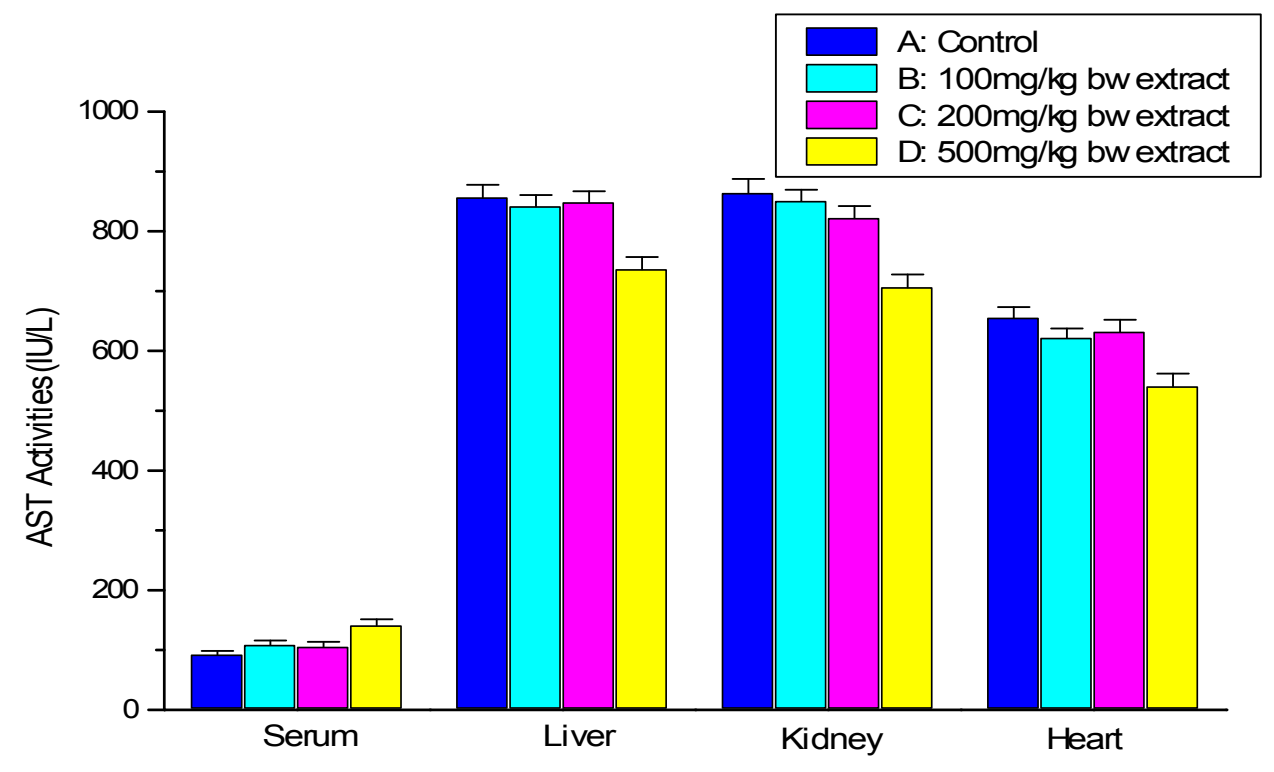

Figure 3: AST activities in serum and tissues of rats administered leaf extract of Ficus exasperata. 


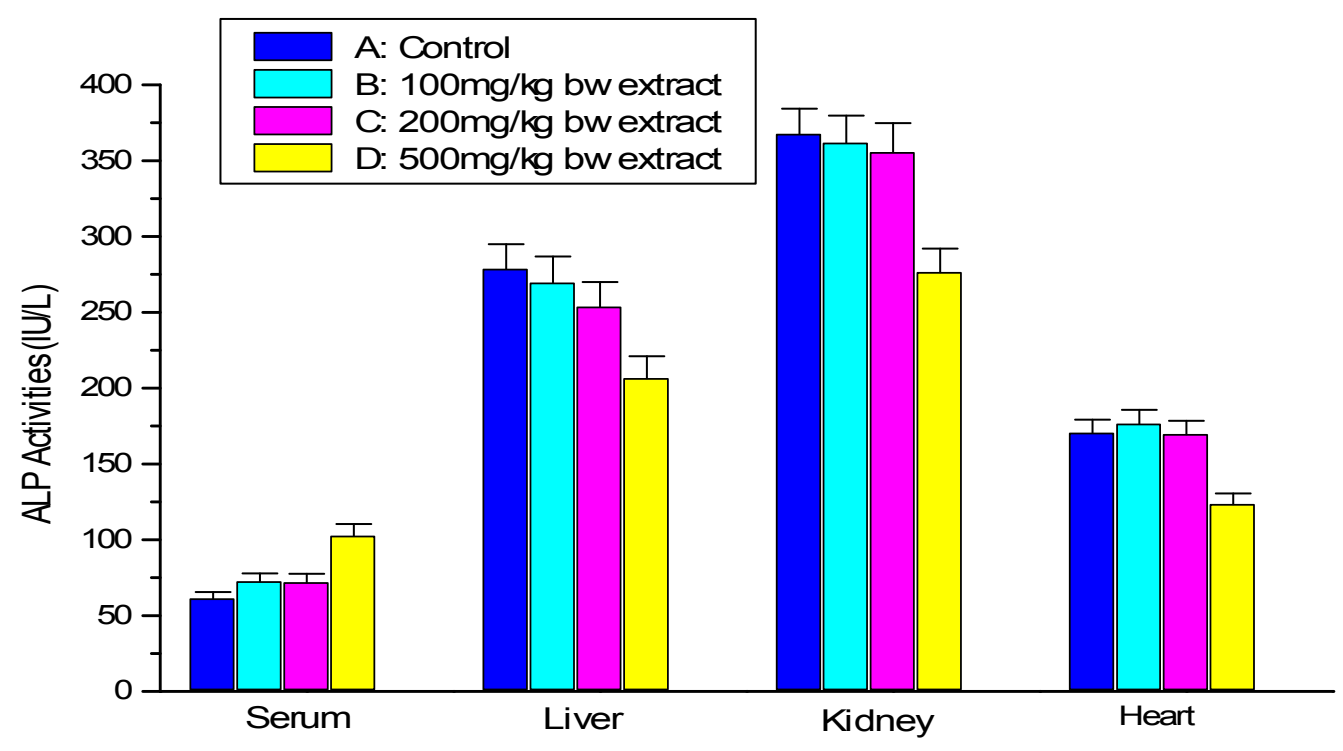

Figure 4: ALP activities in serum and tissues of rats administered leaf extract of Ficus exasperata.

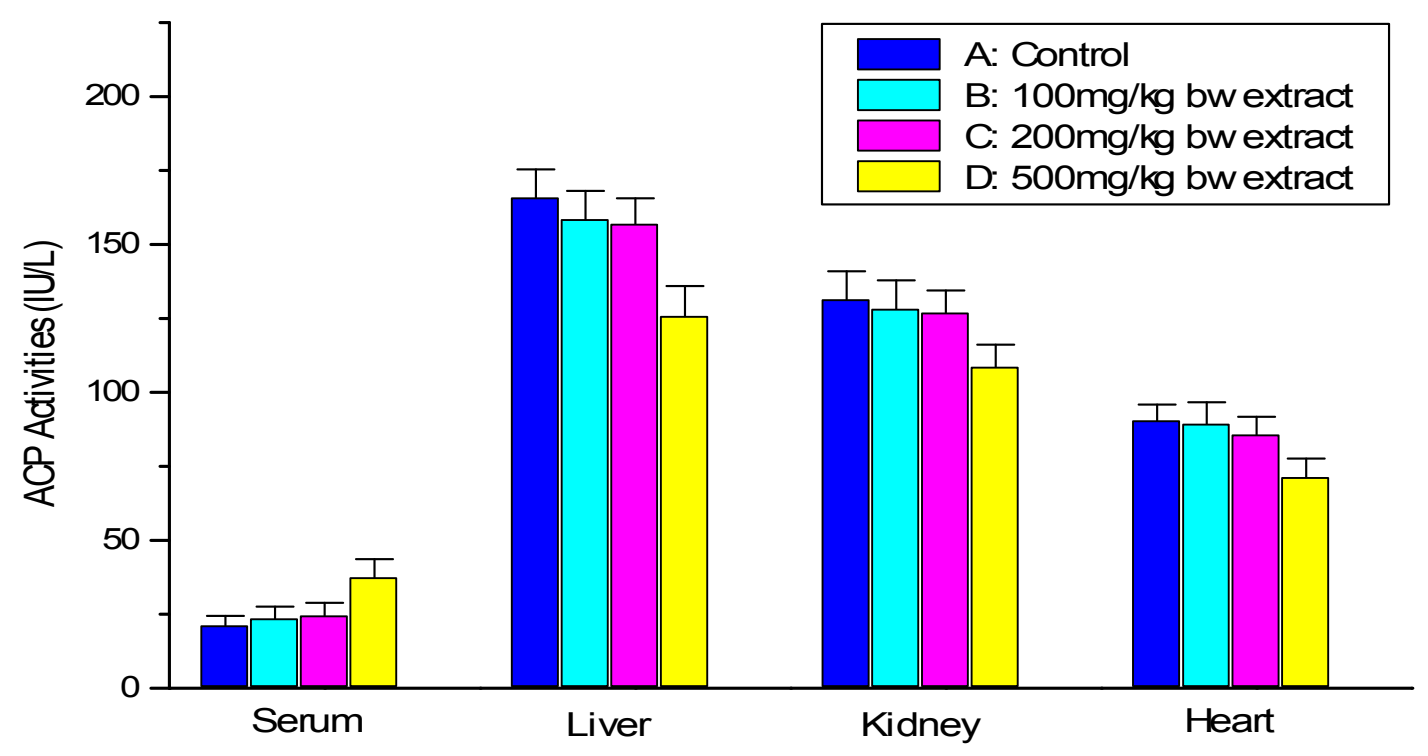

Figure 5: ACP activities in serum and tissues of rats administered leaf extract of Ficus exasperata. 


\section{DISCUSSION}

The present study evaluates the effect of varying concentrations of methanolic leaf extract of Ficus exasperata on some biochemical parameters in rats. Results obtained shows significant increase in growth rate of the rats administered with various concentrations of the extract compared with the control. The observed growth elevation in rats administered the extract suggests that Ficus exasperata increased appetite and feed efficiency, enhanced nutrient metabolism and utilization while it also decreased nutrient loss (Osmund, 2001). This is in accordance with previous reports and observations on the nutritional benefits of the plant (Irene and Chukwunonso, 2006; Bafor and Igbinuwen, 2009). This increased growth rate also indicate that the extract did not cause gastrointestinal irritation which may reduce intestinal absorption of food (Noumi and Yomi, 2001).

The significant increase in relative organ weight in rats administered high dose $(500 \mathrm{mg} / \mathrm{kg} \mathrm{bw})$ of the extract could be ascribed to induction of xenobiotic enzymes leading to increase in protein synthesis in these organs. Body weight and relative organ weight are crucial criteria in biochemical and toxicological examination of xenobiotics. This finding is in conjunction with the finding of Ijeh and Obidoa (2001) who observed increase in the weight of some vital organs following administration of Vernonia amygdalina. The main organs that are involved in the metabolism of xenobiotics and expression of inducible xenobiotic biotransformation enzymes are the liver and kidney. The induction of these enzymes could have accounted for the increase in mean relative organ weight following exposure to the extract (Irene and Chukwunonso, 2006).

Result of this study revealed that administration of $500 \mathrm{mg} / \mathrm{kg}$ bw Ficus exasperata leaf extract caused a significant increase in serum enzymes (ALT, AST, ALP and $\mathrm{ACP}$ ) with their concomitant decrease in the tissues compared with the control. This is an indication that the extract might have caused alteration in biochemical activities in these tissues at the high dose. Activities of ALT and AST are routinely measured clinically as diagnostic tools in assessment of hepatocellular injury and health status of the liver (Omeodu et al., 2008). ALP and ACP are marker enzymes for plasma membrane and are required for proper functioning of organs (Njayou et al., 2010). Measurement of these enzymes is significant in clinical and toxicological studies as changes in their activities are indicative of tissue damage by toxicants. The increase in serum level of these enzymes might be due to their leakage out of the tissues into the blood system due to destruction of their cellular membranes (Azza et al., 2012). Exposure to chemical compounds may result into significant changes in the structure, function, metabolic transformation and concentration of biomolecules, enzymes and even metabolic pathways. These may lead to alteration of various biochemical mechanisms and physiological conditions (Murray et al., 2000).

The observed non alteration of enzyme levels in the serum and tissues of rats administered low and moderate doses (100 and $200 \mathrm{mg} / \mathrm{kg}$ bw respectively) of the extract is indicative that the extract did not pose any threat to the structural and functional integrity of the cells at these doses.

\section{Conclusion}

Results obtained in this study suggest that intake of leaf extract of Ficus exasperata leaf can help to enhance growth in animals. Consumption of the medicinal plant at low and moderate dose has no untoward effect on the liver, kidney and heart but the extract might be toxic to these organs when taken at high dose.

\section{COMPETING INTERESTS}

The authors declare that they have no competing interests. 


\section{AUTHORS' CONTRIBUTIONS}

OIO designed and supervised the research work. He also provided the chemicals and reagents used for the research. JOO was involved in raising of laboratory animals, administration of drugs and analysis.

\section{ACKNOWLEDGEMENTS}

This research is partly sponsored through an Institutional Research Grant obtained from Tertiary Education Trust Fund (TETFUND) of the Federal Government of Nigeria in Collaboration with Osun State University, Osogbo, Nigeria.

\section{REFERENCES}

Ahmed F, Mueen-Ahmed KK, Abedin MZ, Karim AA. 2012. Traditional uses and pharmacological potential of Ficus exasperata Vahl. Systemic Rev. Pharm. 3:15-23.

Amonkan KA, Konan BA, Kouakou KL, Bouafou KGM, Bléyéré NM, Ahui MLB, Zannou TV, Quattara H, Datte JY, Kati-Coulibaly S. 2010. Phytochemical screening and effects of aqueous extract of Ficus exasperata Vahl. 1805 leaves (Moraceae) on blood pressure and contractile activity of the heart in mammals Int. J. Biol. Chem. Sci., 4(3): 681-691.

Armstrong K. 1964. Enzymes: In: Textbook of Clinical Chemistry, Tietz NW (ed) WB Saunders Company; 704-757.

Ayinde BA, Omogbai EK, Amaechina FC. 2007. Pharmacognosy and hypotensive evaluation of Ficus exasperata Vahl (Moraceae) leaf. Acta Pol. Pharm. 64(6): 543-546.

Azza Z, Marnissi F, Naya A, Benjelloun N, Zamyati S, Amrani M, Oudghiri M. 2012. Toxicological evaluation of Thymelaea hirsuta and protective effect against $\mathrm{CCL}_{4}$-induced hepatic injury in rats. Int. J. Biol. Chem. Sci., 6(1): 379393.
Bafor EE, Igbinuwen O. 2009. Acute toxicity studies of the leaf extract of Ficus exasperate on haematological parameters, body weight and body temperature. J. Ethnopharmacol., 123(2): 302-307.

Cousins ON, Michael AH. 2002. Medicinal properties in the diet of Gorillas: An ethno-pharmacological evaluation. African Study Monogr., 23(2): 65-89.

Ijeh II, Obidoa O. 2001. Effects of dietary incorporation of two varieties of Vernonia amygdalina, on relative organ weights of weaning albino rats. Nig. J. Biochem. Mol. Biol. Proceedings Supplement, 16: 50-51.

Ijeh II, Ukweni AI. 2007. Acute effect of administration of ethanol extracts of Ficus exasperata vahl on kidney function in albino rats. J. Med. Plant Res., 1: 27-29.

Ikpeme EV, Udensi O, Ekaluo UB, Efieneokwu N. 2010. Biological response of male Wistar rats to crude extract of Ficus exasperata Vahl. Int. J. Curr. Res., 7: 9-13.

Irene II, Chukwunonso CA. 2006. Body and organ weight changes following administration of aqueous extracts of Ficus exasperata. Vahl on white albino rats. J. Ani. Vet. Adv. 5:277-279.

Joseph B, Raj SJ. 2010. Phytopharmacological and phytochemical properties of three Ficus species-An overview. Int. J. Pharma. Biol. Sci., 1: 246-253.

Lansky EP, Paavilainen HM. 2011. Figs: The genus Ficus Boca Raton. CRC Press: Florida; 13.

Mshana RN, Abbiw DK, Addae-MensahI, Adjanouhoun E, Ahyi MR, Ekpere JA. 2001. Traditional Medicine and Pharmacopoeia: Contribution to the revision of ethnobotanical and floristic studies in Ghana. Accra: Institute for Scientific and Technological Information. p. 919. 
Murray RK, Granner PA, Mayer PA, Rodwell VW. 2000. Harper's Biochemistry (20th edn). McGraw-Hill; 594-602.

Njayou F, Moundipa P, Donfack J, Chuisseu D, Tchana A, Ngadjui B, Tchouanguep F. 2010. Hepatoprotective, antioxidant activities and acute toxicity of a stem bark extract of Erythrina senegalensis DC. Int. J. Biol. Chem. Sci., 4(3): 738747.

Noumi E, Yomi A. 2001. Medicinal plants used for intestinal diseases in Mbalmayo Region, Central Province, Cameroon. Fitoterapia, 72: 246-254.

Odunbaku OA, Ilusanya OA, Akasoro KS. 2008. Antibacterial activity of ethanolic leaf extract of Ficus exasperata on Escherichia coli and Staphylococcus albus. Sci. Res. Essay. 3:562-564.

Omeodu SI, Monanu M, Anosike EO. 2008. Effect of aqueous extract of African mistletoe (Tapinanthus bangwesis) on some serum enzymes of rats with carbon tetrachloride- induced liver damage. Int. J. Biol. Chem. Sci., 2(4): 448-455.

Osmund CE. 2001. Basic Biochemistry of Food Nutrients ( $1^{\text {st }}$ edn). Immaculate Publication: Enugu, Nigeria.
Oyewole OI, Adanlawo IG, Arise RO. 2013. Serum and tissue lipid profile In Wistar rats administered leaf extract of Ficus exasperata. Annals Biol. Res., 4(2): 288-291.

Reitman S, Frankel S. 1957. A colorimetric method for the determination of serum ALT and AST. Am. J. Clin. Pathol. 28: 56-63.

Sonibare MO, Isiaka AO, Taruka MW, Williams NS, Soladoye M, Emmanuel O. 2006. Constituents of Ficus exasperata leaves. Natural Product Communications: 23-26.

Woode E, Poku RA, Ainooson GK, BoakyeGyasi E, Abotsi WK, Mensah TL. 2009. An evaluation of the antiinflammatory, antipyretic and antinociceptive effects of Ficus exasperata (Vahl) leaf extract. $J$. Pharmacol. Toxicol., 4: 138-151.

Woode E, Poku RA, Abotsi WK. 2011. Anxiolytic-like effects of a leaf extract of Ficus exasperata Vahl (Moraceae) in Mice. West Afr. J. Pharm., 22: 7581.

Wright PJ, Plummer DT. 1974. The use of urinary enzyme measurement to detect renal damage caused by nephrotoxic compounds. Biochem. Pharmacol., 23: 65-73. 